\title{
統計値と水域形状を用いた交通環境のマクロ的評価
}

\author{
田中 隆博* ・井上 欣三**
}

\section{Macroscopic Evaluation of the Traffic Environment by Utilization of Statistical Data and Figure of Water Area}

\author{
Takahiro TANAKA and Kinzo INOUE
}

\begin{abstract}
The technique of simulation is often used to evaluate the traffic condition in the present or in the future. However, the special devices, observed data, and high cost are needed to carry out the simulation. In addition, as the simulation process is too complicated, so that such simulation method is not easy to understand for the person who is not having speciality knowledge.

In this paper, the authors estimated the network of maritime traffic by utilizing the statistical data of ships' port entry and the simplified figure of water area of the port. The estimation of number of encountering ships was attempted without such special devices and observed data, and compared with the observed number. Moreover, application to the prediction of traffic environmental condition was indicated.
\end{abstract}

\section{1.はじめに}

海上交通の航行環境の現状を評価したり、これに 影響を及ぼす水域の埋立てや構造物の建設による航 行環境の変化に伴う船舶の航行状態を予測、評価す る手法としてシミュレーションの技法が用いられ る。このシミュレーションの技法は、特別な機材や 膨大な実航跡データを要するなどの理由によって、 その過程が複雑化されがちである。それゆ之、専門 的知識を持ち合わせていない者にとっては必ずしも 馴染みやすい手法とはいえない。

そこで、本研究では、港湾統計など広く公開され ている船舶の出入港に関する統計值抢よび対象水域 を簡素化した形状を用いて評洒対象水域内における 船舶交通のネットワーク、すなわち、船舶の通る路 とその量を推定する。そして、交通環境を表現する 最も基本的なインデックスのひとつである船舶と船 舶との出会い回数を多大な実航跡デー夕を用いるこ となく、記述的かつマクロ的に求める。ここでは、 神戸港のポートアイランド、六甲アイランド間を対
象水域として、図 1 に示す流れでネットワークを想 定する。ここにいう記述的かつマクロ的とは、個々 の船舶の詳細な動きについては考慮せず、算術的に 大略の出会い回数を算出することを意味する。

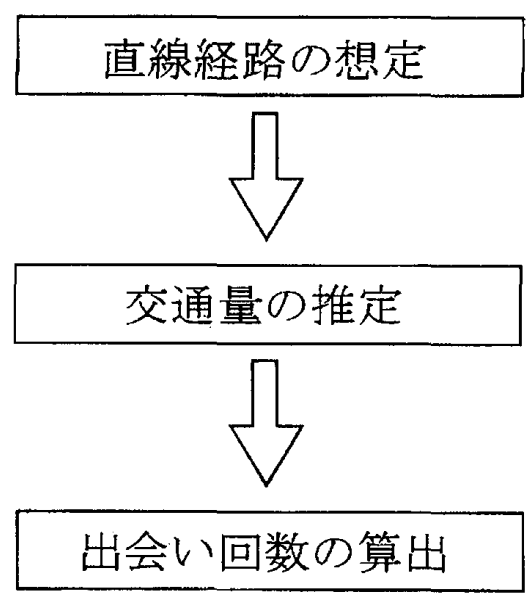

図 1 出会い回数算出の流れ

* 学生会員 神戸商船大学大学院 （T658-0022 神戸市東灘区深江南町5-1-1）

**正 会 員 神戸商船大学 （T658-0022 神戸市東灘区深江南町5-1-1） 


\section{2. 出会い回数の算出法}

\section{1 経路の想定}

まず、対象水域を水域と陸域で 2 值画像化し、水 域形状の中間軸を抽出し、これをもとにノードとリ ンクを想定する。図 2 が対象水域から抽出した中間 軸である。そして、連結したノード間を直線で結合 し簡略化する。ノード間には平均水域幅の平行水路 を想定する。ここでは、中間軸の抽出手法として Voronoi Medial Axis (1) を用いているが、水域全体 をマクロ的に評価する場合、細線化など形状簡素化 手法を用いても同等の結果が得られる。

図 2 では、一般に大型船舶が航行しない狭险な部 分にもリンクが生じていることがわかる。また、端 点付近に複数ノードが生成されている場合もある。

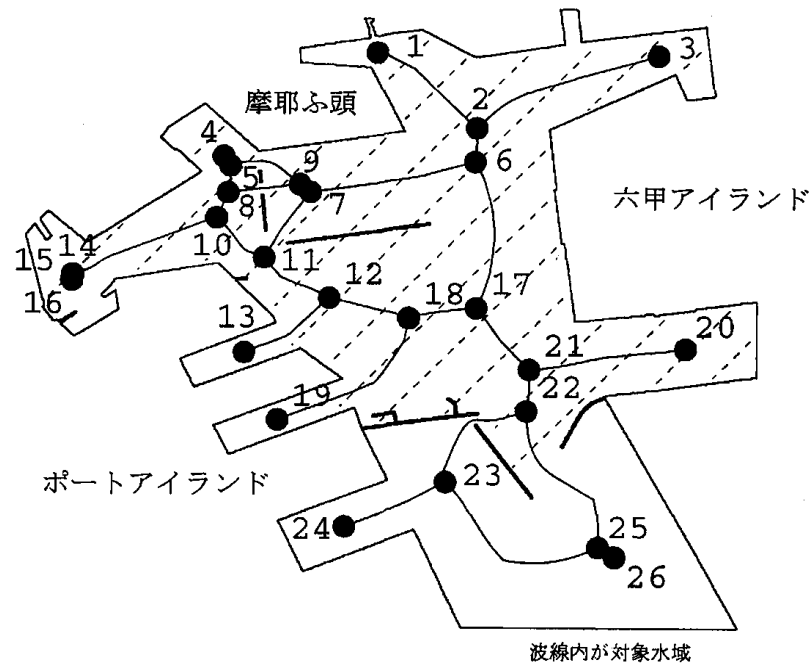

困 2 対象水域および中間軸

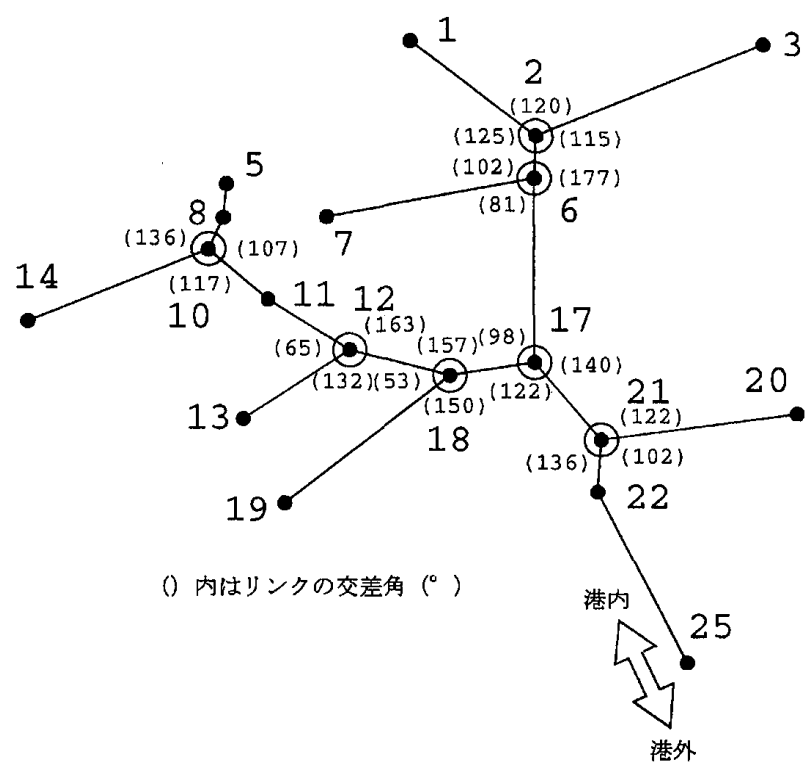

図 3 想定した経路
これらのリンクまたはノードでの出会い回数は計算 上は微小であり無視できるため、困 3 のようにさら に簡素化した経路を想定した。

\section{2 交通量の推定}

一般的に、ある対象水域における船舶の交通量や 通航状況を知るためには、交通実態観測に基づく以 外に手段がない。しかし、この交通実態観測は多大 な労力を必要とする。そこで、神戸港の船舶の入港 に関する統計值 ${ }^{(2)}$ から、対象水域の交通量の推定を 試みた。この上うな統計值から、各けい船岸への入 出港船の船型分布を詳細に知ることはできないが、 一定の規則に基づけば入出港船舶の総卜ン数の配分 を行うことができる。

神戸港の統計值では、外航船抒よび内航船施設別 係留状況が示されており、1998年においては、けい 留船隻数は公共けい留施設 (公共バース) が 42 , 254 (隻) [71.5\%]、私設けい留施設（私設バース） が16,735 (隻) [28.3\%]、けい留施設不明が69 (隻) [0.2\%] であった。総卜ン数で見ると公共けい留施 設が237,751,387(総トン) [89.7\%]、私設けい留施 設が27,344,233（総トン） [10.3\%]、けい留施設不 明が 13,181 (総トン） $[0.0 \%]$ であった。そして、 次の手続きによって、各けい留施設への入出港総卜 ン数の配分および各ノードへ流入する総トン数を推 定した。

（a）公共けい留施設について、隣接するけい留 施設の総トン数がまとめて集計値として示されてい る場合は、船舶の総トン数が全長の 3 乗に比例する ことから、図 4 に示すように各けい留施設の延長の 3 乗で総卜ン数を比例配分

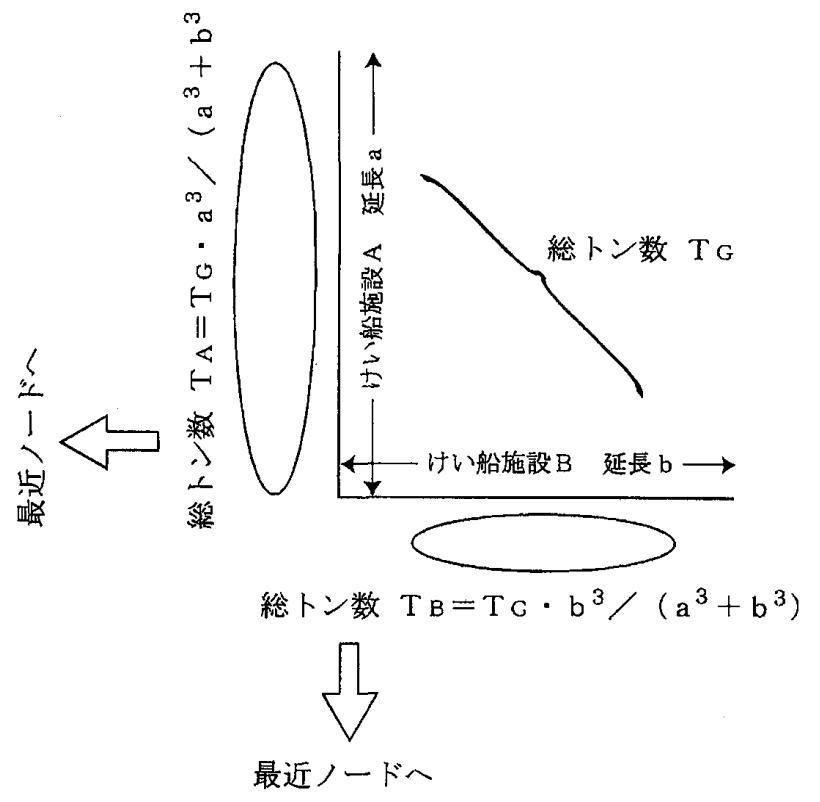

図 4 総卜ン数で配分した係留施設への交通量 
表 1 各ノードでの総トン数で配分した発生交通量 とルート

\begin{tabular}{|c|c|c|}
\hline $1-i^{2}$ & 交通量（トン/日) & 出港肪一ト（入港の場合は同交通量が逆をたどる） \\
\hline 1 & 2,392 & $1-2-6-17-21-22-25$ \\
\hline$\overline{2}$ & 53,531 & $2-6-17-21-22-25$ \\
\hline 3 & 2,851 & $3-2-6-17-21-22-25$ \\
\hline 5 & 2,180 & $5-8-10-11-12-18-17-21-22-25$ \\
\hline 6 & 1,348 & $6-17-21-22-25$ \\
\hline 7 & 1,118 & $7-6-17-2 l-22-25$ \\
\hline 10 & 5,010 & $10-11-12-18-17-21-22-25$ \\
\hline 12 & 1,065 & $12-18-17-21-22-25$ \\
\hline 13 & 5,793 & $13-12-18-17-21-22-25$ \\
\hline 14 & 3,723 & $14-10-11-12-18-17-21-22-25$ \\
\hline 17 & 13,849 & $17-21-22-25$ \\
\hline 19 & 15,851 & $19-18-17-21-22-25$ \\
\hline 20 & 42,090 & $20-21-22-25$ \\
\hline 21 & 27,020 & $21-22-25$ \\
\hline 計 & 177,821 & \\
\hline
\end{tabular}

（b）私設けい留施設については、集計值が示さ れているのみで、けい留場所の詳細が公表されてい ないため、(a) 同様に、各私設けい留施設の延長の 3 乗で集計值を比例配分

（c）配分した総トン数を最も近いノードへの総 トン数とし、この総トン数は最短ルートを経て港外 へ流出し消失、また、逆のルートを経て同ノードに て消失する

以上の手続きによって対象水域のノードへの総卜 ン数で配分した交通量およびルートを表 1 に示す。

\section{3 出会い回数の算出}

ここに交通環境をマクロ的に評価することは、船 舶が航行中に他の船舶とどれくらい出会うかを求め ることを意味する。ここでは、船舶と船舶との出会 いを「両船舶がそのまま直進すれば両船舶間の相対 距離が一定值以下になる場合」と定義する。

2 つの交通流 $\mathrm{A}$ とBが交差する場合、単位面積、単 位時間あたり一定の出会い半径 $r(\mathrm{~km})$ 内での出会い 頻度入は、式(1)で表される(3)。

$\lambda=2 \cdot \mathrm{r} \cdot \mathrm{d}_{\mathrm{A}} \cdot \mathrm{d}_{\mathrm{B}} \cdot \mathrm{V}_{\mathrm{R}}$

ここで、 $\mathrm{d}_{\mathrm{A}}$ : 交通流Aの航行密度 $\left(\right.$ 隻 $\left./ \mathrm{km}^{2}\right)$ $\mathrm{d}_{\mathrm{B}}$ : 交通流Bの航行密度 $\left(\right.$ 隻 $\left./ \mathrm{km}^{2}\right)$ $\mathrm{V}_{\mathrm{R}}$ : 相対速力 $(\mathrm{km} / \mathrm{h})$

総トン数で配分した交通量（以下、単に「交通量」 という。）は港外から流入し、それぞれのけい留施設 に最も近いノードで消失（着栈したものとする）し、 また、同量の交通量が同ノードから最短ルートを経 て港外へ流出するものと考える。図 5 (a)に示すよ うに、リンクにおける単位時間あたりの出会い頻度 $\lambda_{\mathrm{L}}$ は、式(2)で表すことができる。

$$
\begin{array}{r}
\lambda_{\mathrm{L}}=2 \cdot \mathrm{r} \cdot \mathrm{d}_{\mathrm{A}} \cdot \mathrm{d}_{\mathrm{B}} \cdot \mathrm{D} \cdot \mathrm{W}_{\mathrm{L}} \cdot \mathrm{V}_{\mathrm{R}} \\
\text { ここで、 } \mathrm{W}_{\mathrm{L}} \text { : リンクの } \\
\mathrm{D} \text { ：リンク幅 }(\mathrm{km})
\end{array}
$$

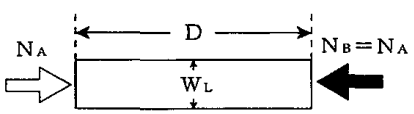

(a) リンク

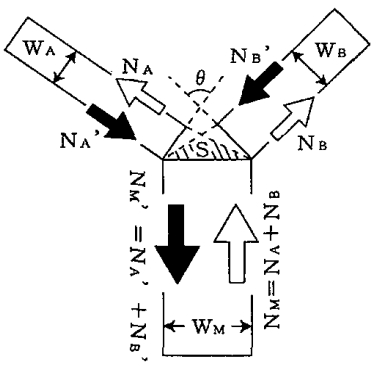

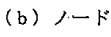

困 5 リンクおよびノ一ドでの出会いを求める図

また、ノード付近における出会いの状況を表現す ることは非常に難しいが、ここでは、幹となるリン ク（対象とするノードにつながる最大交通量のリン ク）と他のリンクを図 5 (b)に示すように配置し、幾

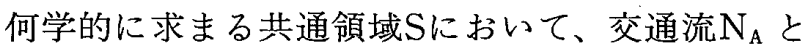
$\mathrm{N}_{\mathrm{B}}{ }^{\prime}$ および $\mathrm{N}_{\mathrm{B}}$ と $\mathrm{N}_{\mathrm{A}}{ }^{\prime}$ が出会うものと考え、Sでのそ れぞれの出会い頻度 $\lambda_{\mathrm{N}}$ は、式 (3)で表すこととした。

$$
\begin{aligned}
\lambda_{\mathrm{N}} & =2 \cdot \mathrm{r} \cdot \mathrm{d}_{\mathrm{A}} \cdot \mathrm{d}_{\mathrm{B}} \cdot \mathrm{A} \cdot \mathrm{V}_{\mathrm{R}} \quad \cdots \ldots \ldots \ldots \ldots \ldots \ldots \ldots \ldots \ldots \ldots \ldots \\
& こ こ て ゙ 、 A ： \text { 共通領域 } \mathrm{S} \text { 面積 }\left(\mathrm{km}^{2}\right)
\end{aligned}
$$

さらに、船舶の総トン数 $G$ （トン）と全長 $\mathrm{L}(\mathrm{m})$ との関係が、式(4)で表される(4)とすると、

$$
\mathrm{G}=\mathrm{L}^{3} / 250
$$

式（2）で表したリンクにおける出会い頻度 $\lambda_{\mathrm{L}}$ は、式 (5)のとおり変形できる。

$$
\begin{aligned}
& \lambda_{\mathrm{L}}=2 \cdot \mathrm{r} \cdot\left(\mathrm{N}_{\mathrm{A}} /(\mathrm{V} \cdot \mathrm{D})\right)^{2} \cdot \mathrm{D} \cdot \mathrm{W}_{\mathrm{L}} \cdot \mathrm{V}_{\mathrm{R}} \\
& =2 \cdot \mathrm{r} \cdot\left(\mathrm{T}_{\mathrm{A}} /(\mathrm{G} \cdot \mathrm{V} \cdot \mathrm{D})\right)^{2} \cdot \mathrm{D} \cdot \mathrm{W}_{\mathrm{L}} \cdot \mathrm{V}_{\mathrm{R}} \\
& =2 \cdot \mathrm{m} \cdot\left((250 \cdot \mathrm{G})^{1 / 3} / 1,000\right) \\
& \cdot\left(\mathrm{T}_{\mathrm{A}} /\left(\mathrm{G} \cdot \mathrm{V}_{\mathrm{A}} \cdot \mathrm{D}\right)\right)^{2} \cdot \mathrm{D} \cdot \mathrm{W}_{\mathrm{L}} \cdot \mathrm{V}_{\mathrm{R}} \\
& =\mathrm{k}_{\mathrm{L}} \cdot \mathrm{m} / \mathrm{G}^{5 / 3} \\
& \text { ここで、 } N_{\mathrm{A}} \text { : 交通流Aの交通量 (隻/h) } \\
& \mathrm{V} \text { : 交通流の速力 }(\mathrm{km} / \mathrm{h}) \\
& \mathrm{T}_{\mathrm{A}} \text { : ノードの交通量 (トン/h) } \\
& \mathrm{G} \text { : 換算総トン数（トン/隻） } \\
& \mathrm{m} \text { : 換算総トン数の船舶の全長に } \\
& \text { 対する出会い半径の比 } \\
& \mathrm{k}_{\mathrm{L}} \text { : 定数 }
\end{aligned}
$$

すなわち、各リンクへ流入する交通量がわかれば、 換算総トン数G(トン)にしてどのくらいの出会い頻 度や出会い回数があるか推定することができる。以 下、式 (5)で、定数 $\mathrm{k}_{\mathrm{L}}$ をリンクの出会い係数と呼ぶこ ととする。

また、式(3)を、

$$
\begin{aligned}
\lambda_{\mathrm{N}} & =2 \cdot \mathrm{r} \cdot \mathrm{N}_{\mathrm{A}} \cdot \mathrm{N}_{\mathrm{B}}(\mathrm{I} /(\mathrm{V} \cdot \mathrm{D}))^{2} \cdot \mathrm{A} \cdot \mathrm{V}_{\mathrm{R}} \\
& =2 \cdot \mathrm{r} \cdot \mathrm{T}_{\mathrm{A}} \cdot \mathrm{T}_{\mathrm{B}}(1 /(\mathrm{G} \cdot \mathrm{V} \cdot \mathrm{D}))^{2} \cdot \mathrm{A} \cdot \mathrm{V}_{\mathrm{R}}
\end{aligned}
$$




$$
\begin{aligned}
& =2 \cdot \mathrm{m} \cdot\left(\left(250 \cdot \mathrm{G}^{1 / 3}\right) / 1,000\right) \\
& \cdot \mathrm{T}_{\mathrm{A}} \cdot \mathrm{T}_{\mathrm{B}}(1 /(\mathrm{G} \cdot \mathrm{V} \cdot \mathrm{D}))^{2} \cdot \mathrm{A} \cdot \mathrm{V}_{\mathrm{R}} \\
& =\mathrm{k}_{\mathrm{N}} \cdot \mathrm{m} / \mathrm{G}^{5 / 3} \\
& \text { ここで、 } \mathrm{N}_{\mathrm{B}} \text { : 交通流Bの交通量（隻 } / \mathrm{h} \text { ) } \\
& \left.\mathrm{T}_{\mathrm{B}} \text { : ノードの交通量（トン } / \mathrm{h}\right) \\
& \mathrm{k}_{\mathrm{N}} \text { : 定数 }
\end{aligned}
$$

式(6)のとおり変形することで同様の定数はノード

\begin{tabular}{|c|c|c|c|c|c|}
\hline リンク & $(\mathrm{km})$ & 平均幅 $(\mathrm{km})$ & 面積 $\left(\mathrm{km}^{2}\right)$ & 交通蛙（ト／日) & 出会い係数 $\mathrm{k}_{\mathrm{L}}(10 \mathrm{kt})$ \\
\hline $1-2$ & 1.498 & 0.489 & 0.732 & 2,392 & 41 \\
\hline $2-3$ & 2.329 & 0.440 & 1.026 & 2,851 & 102 \\
\hline $2-6$ & 0.404 & 0.868 & 0.350 & 58,773 & 3,798 \\
\hline $5-8$ & 0.320 & 0.351 & 0.112 & 2,180 & 10 \\
\hline $6-7$ & 1.976 & 0.566 & 1.119 & 1,118 & 10 \\
\hline $6-17$ & 1.811 & 0.854 & 1.546 & 61,239 & 18,784 \\
\hline $8-10$ & 0.330 & 0.452 & 0.149 & 2,180 & 8 \\
\hline $10-11$ & 0.754 & 0.392 & 0.296 & 10,913 & 541 \\
\hline $10-14$ & 1.796 & 0.394 & 0.708 & 3,723 & 149 \\
\hline $11-12$ & 0.927 & 0.471 & 0.437 & 10,913 & 553 \\
\hline $12-13$ & 1.217 & 0.234 & 0.284 & $5,7.93$ & 413 \\
\hline $12-18$ & 0.968 & 0.869 & 0.841 & 17,771 & 830 \\
\hline $17-18$ & 0.805 & 1.050 & 0.845 & 33,622 & 2,047 \\
\hline $17-21$ & 0.963 & 0.981 & 0.945 & 95,033 & 27,407 \\
\hline $18-19$ & 2.113 & 0.267 & 0.565 & 15,851 & 4,691 \\
\hline $20-21$ & 1.847 & 0.507 & 0.937 & 42,090 & 15,245 \\
\hline $21-22$ & 0.500 & 0.623 & 0.311 & 177,821 & 59,862 \\
\hline $22-25$ & 1.991 & 0.503 & 1.002 & 177,821 & 295,355 \\
\hline
\end{tabular}
にも求まり、その定数 $\mathrm{k}_{\mathrm{N}}$ をノードの出会い係数と呼 ぶこととする。こうして、リンクやノードの出会い 係数から単位時間あたりの水域全体の出会い頻度 $\lambda_{\mathrm{T}}$ を、

\section{表 2 （a） 各リンクの要目}

\section{表 2 （b）交差ノードにおける要目}

\begin{tabular}{|c|r|r|}
\hline$ر-F$ & 面䅞 $\left(\mathrm{km}^{2}\right)^{2}$ & 会W保数 $\mathrm{k}_{\mathrm{N}}(10 \mathrm{kt})$ \\
\hline 2 & 0.117 & 211 \\
\hline 6 & 0.210 & 1,018 \\
\hline 10 & 0.072 & 111 \\
\hline 12 & 0.056 & 3,098 \\
\hline 18 & 0.089 & 2,448 \\
\hline 17 & 0.244 & 62,818 \\
\hline 21 & 0.261 & 115,366 \\
\hline
\end{tabular}

$$
\lambda_{\mathrm{T}}=\left(\Sigma \mathrm{k}_{\mathrm{L}}+\Sigma \mathrm{k}_{\mathrm{N}}\right) \cdot \mathrm{m} / \mathrm{G}^{5 / 3}
$$

式 (7)のとおり任意の船型に換算した量として算術 的に求めることができる。図 3 のリンクおよU゙ノ一 ドの出会い係数等の要目を表 2 に示す。

以上の手続きによって、統計值から算術的に出会 い頻度や出会い回数を算出することができる。ここ では追越しによる出会いが考慮されていないもの の、港内などの限定された水域においては、その回 数は多くないと考えられる。このことは、次章の交 通観測結果からも明らかである

\section{3. 交通実態観測}

\section{1 観測の方法および結果の概要}

2 章で示した出会い回数の算出法による出会い回 数と現実の交通実態から求めた出会い回数とを対比 するデータを得るために、35 mm SLRカメラ撮影に よる交通実態観測を行った。観測日時、機材等の概

\section{表 3 交通実態観測の概要}

1. 観湘日時

(1) 1999 年 7 月 30 日 $0500 \sim 2000$

（2）同年9月18日 $0500 \sim 2000$

2. 観測場所

神戸市灘区長峰台 標高約 $220(\mathrm{~m})$

3. 観測機材

\begin{tabular}{|c|c|c|c|c|c|c|c|c|c|}
\hline 船種，船型別年 & 算 & & & & & & & & 単位：隻 \\
\hline 称而 & $\sim 50$ & $50 \sim 200$ & $200 \sim 500$ & $500 \sim 1,000$ & $1,000 \sim 3,000$ & $3,000 \sim 5,000$ & $5,000 \sim 10,000$ & $10,000 \sim$ & 柿 \\
\hline 貨物船 & & $56(28)$ & $25(19)$ & (1) & $2(5)$ & $\begin{array}{r}5(3) \\
\end{array}$ & & 2 & $90(56)$ \\
\hline コンテナ船 & & & & $3(2)$ & 2(1) & $4(2)$ & $2(4)$ & $3(2)$ & $14(11)$ \\
\hline 自動車専用船 & & & & & & 4 & & & 4 \\
\hline 客船 & & 4(1) & & & & & & & $4(1)$ \\
\hline 油タンカー & & $4(2)$ & $5(2)$ & & & & & 1 & $10(4)$ \\
\hline 液体タンカー & & & (1) & & & & & & (1) \\
\hline 七メントタンカー & & & & & & 1 & & & 1 \\
\hline 鲐石タンカー & & & & & & & & $4(1)$ & $4(1)$ \\
\hline 多グボート & & $88(50)$ & & & & & & & $88(50)$ \\
\hline タグボート(被电) & $37(33)$ & 2 & & & & & & & $39(33)$ \\
\hline その他 & 8 & $8(8)$ & & & & & & & $16(8)$ \\
\hline 䧴船 & $160(158)$ & & & & & & & & $160(158)$ \\
\hline 計 & $205(191)$ & $162(89)$ & $30(22)$ & $3(3)$ & $4(6)$ & $14(5)$ & $2(4)$ & $10(3)$ & $430(323)$ \\
\hline
\end{tabular}

$35 \mathrm{~mm}$ S L R （85mm F1.4） 五脚固定

\begin{tabular}{|c|c|c|c|c|c|c|c|c|}
\hline 船南 & $\sim 50$ & $50 \sim 200$ & $200 \sim 500$ & $500 \sim 1000$ & $1,000 \sim 3,000$ & $3000 \sim 5000$ & $15,000 \sim 10,000$ & $\frac{\text { 单位: } \mathrm{kt}}{1000 \sim}$ \\
\hline 貨物船 & & $10.2(10.6)$ & $11.7(10.0)$ & $(7.6)$ & $11.2(9.2)$ & $9.7(8.6)$ & & 8.3 \\
\hline コシテナ船 & & & & $12.6(7.9)$ & $9.8(8.9)$ & $10.3(9.0)$ & $11.5(8.9)$ & $7.6(7.3)$ \\
\hline 自動車専用船 & & & & & & 11.4 & & \\
\hline 客船 & & $13.6(15.1)$ & & & & & & \\
\hline 酒タンカー & & $10.9(10.8)$ & $11.2(13.1)$ & & & & & 8.5 \\
\hline 液体タンカー & & & $(10.1)$ & & & & & \\
\hline セメントタンカー & & & & & & 10.3 & & \\
\hline 鉱石タンカー & & & & & & & & $8.1(10.0)$ \\
\hline タグボート(被曳) & 4. $1(4.9)$ & 6.8 & & & & & & \\
\hline
\end{tabular}

I SO 100 (一部増感現像) モノクロフィルム 双眼鏡 $(7 \times 42 \mathrm{~mm})$

ワイドバンドレシーバ（国際V H F 受信）

記録用紙（船型，船種，管制信号の状況等記入）

表 4 交通実態観測集計の概略 
要を表 3 に示す。この実態交通観測集計の結果の概 要は表 4 に示すとおりである。7月30日は小型船も含 めた総隻数が430（隻）、一方、9月18日は323（隻） であり、両日間では約 100 隻の差があった。大型船が 入出港することは、これを支援するためのタグボー ト、パイロットボート、はしけなどの動きとも密接 に関係し、全体の船舶の交通量は大型船の入港隻数 の日変動の数倍の動きとして現れる。理想的には長 期観測を行って、この日変動を相殺できるだけの デー夕に基づく議論も必要であるが、それを得るた めには膨大な労力と経費を要する。今回は 2 日間の 交通実態観測加求めた出会い回数と算術的に求め た出会い回数とを対比した。

なお、表 4 (b) から、この水域における船舶の速力 は、船型が大きくなるにつれ低下する傾向がみられ るものの、ほぼ10土2(kt)の範囲であった。

\section{2 航跡データの取得方法}

観測両日とも 3 分間隔で同水域の撮影を行った。 撮影済みのフィルムは現像した後、フィルムスキャ ナ (2,720 dpi) によってデジタル化した。このデジ タル化した画像上の座標值 $(\mathrm{x}, \mathrm{y})$ から地上座標 $(\mathrm{X}$, $\mathrm{Y})$ への変換は、ここでは限定された水域であるので 平面への変換を考え、式 (8)で表される射影変換 ${ }^{(5)}$ を用いた。

$$
\begin{aligned}
& \mathrm{X}=\left(\mathrm{b}_{1} \cdot \mathrm{x}+\mathrm{b}_{2} \cdot \mathrm{y}+\mathrm{b}_{3}\right) /\left(\mathrm{b}_{7} \cdot \mathrm{x}+\mathrm{b}_{8} \cdot \mathrm{y}+1\right) \\
& \mathrm{Y}=\left(\mathrm{b}_{4} \cdot \mathrm{x}+\mathrm{b}_{5} \cdot \mathrm{y}+\mathrm{b}_{6}\right) /\left(\mathrm{b}_{7} \cdot \mathrm{x}+\mathrm{b}_{8} \cdot \mathrm{y}+1\right) \\
& \text { ここで、} \mathrm{b}_{\mathrm{i}}(\mathrm{i}=1, \cdots, 8): \text { 未知定数 }
\end{aligned}
$$

式(8)の未知定数 $\mathrm{b}_{\mathrm{i}}$ は 4 点の既知点によって定める ことができる。ここでの手法は、少ない人数で観測 ができること、また、写真フィルムとフィルムスキャ 十を用いることで、非常に高解像度の画像が低コス トで得られることが利点である。今回の観測場所か らは、1画素に相当する長さから算出すると、水域の 中央部付近の水平方向では $1(\mathrm{~m})$ 未満の精度で船舶 の位置が読みとれるはずであるが、実際にはデジ夕 ル化する際のフィルムの平坦性やフィルムの粒状性 の問題、撮影レンズの解像度やディストーションの 影響などによって絶对誤差(4点を基準にして得られ た平面上の座標と地上座標との差）にもばらつきが あった。そのため、絶対誤差の平均が最小 (7月30日 については26.9 (m)、9月18日については30.5(m)) となる基準画像を選定し、この基準画像と各撮影コ マとを画像処理ソフトウエアによって合成し、対象 船舶周辺に写っている固定物標でマッチングをする ことによって、相対的な䛊差が小さくなるように配 慮した。そして、得られた船舶の地上座標 $(\mathrm{X}, \mathrm{Y})$

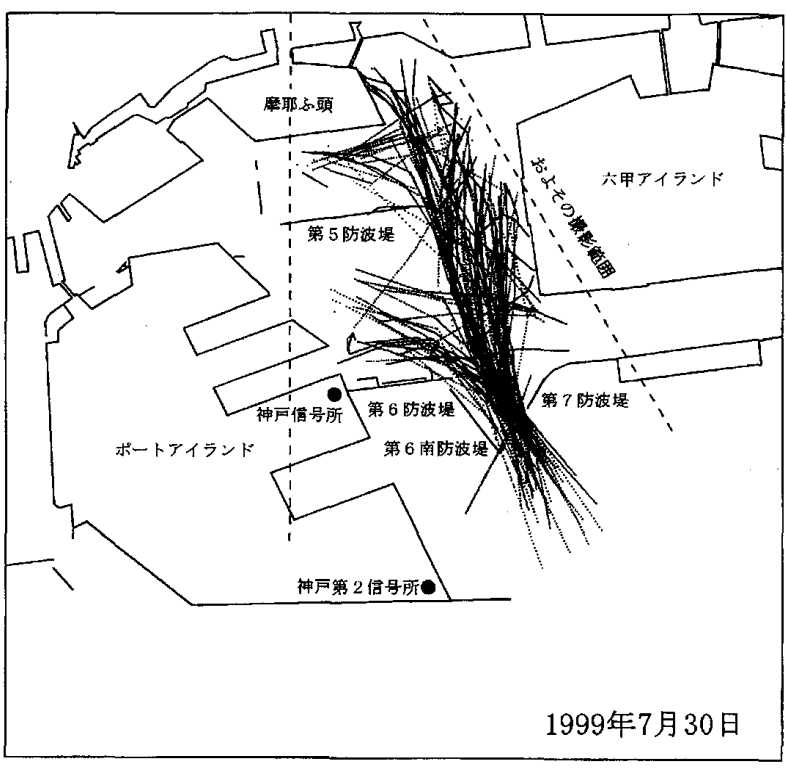

図 6 射影変換によって得られた航跡

を5秒間隔で補間した結果を図 6 に示す。同図におい ては、今回は撮影間隔を 3 分としたため、急変針を伴 う場合には、防波堤上を横切っている航跡も見受け られるが、バースへの接岸航跡から判断して、おお むね良好な変換がなされているといえる。

以上の手続きから得られた航跡を、計算機上で再 現させ、撮影範囲における船舶と船舶とが一定距離 以下となる出会い回数を求めた。ただし、今回の撮 影間隔では、避航操船などについての詳細な船体運 動の過程をとらえることができないため、至近の出 会い回数についての信頼性はあまり高くないものと 考えられる。

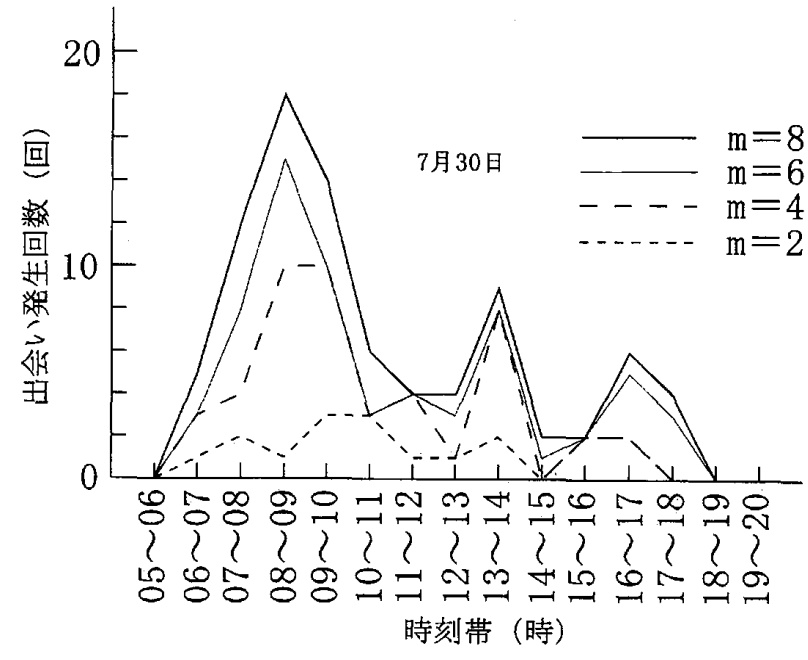

図 7 時刻帯別出会い発生状況（7月30日） 


\section{4. 出会い回数の算出結果と実態観測との 対応}

図 7 は、7月30日の実態観測から得られた各時刻 帯別の出会い回数を示すグラフである。同図から、 08、13、16時頃にピークがあることがわかる。特に、 08時頃のピークが顕著であるのは、

-入港船舶の一方向的な流れに対し、少数であっ てもこれに反航する出港船や通過船があると、出会 い回数を増加させる

・入港船舶が逐次入港し、「追いつき」の状態が生 じることがある

ためである。なお、観測両日とも入港船舶が集中す る07時前後に同水域内での追越しは目視観測では確 認できなかった。

つぎに、 2 章で述べた出会い回数算出法による出 会い回数については、以下の 4 ケースで算出した。

(1)：24時間かけて交通量が均一に出入港すると想 定

(2)：12時間かけて交通量が均一に出入港すると想 定

(3)：(1)について撮影範囲を考慮

(4)：(2)について撮影範囲を考虑

それぞれ船舶の全長に対する出会い半径の比西を 2 ～8の範囲で変化させて出会い回数を算出した結果 と交通実態観測によって観測された出会いの回数を 図 8 に示す。なお、交通実態観測によって出会いが 観測された船舶の総トン数が図 8 に示すようにおお むね3,000〜 5,000（トン）であったことから、ケー ス(1)～(4)の算出では換算総卜ン数 $\mathrm{G} 44,000$ (トン) とした。また、表 4 (b)に示すように、対象水域中央 における船舶の速力が $10(\mathrm{kt})$ 前後であったことか ら、速力Vは10 (kt) とし、交通実態観測からは、 50〜200 (トン) のカテゴリー以上の船舶を対象とし

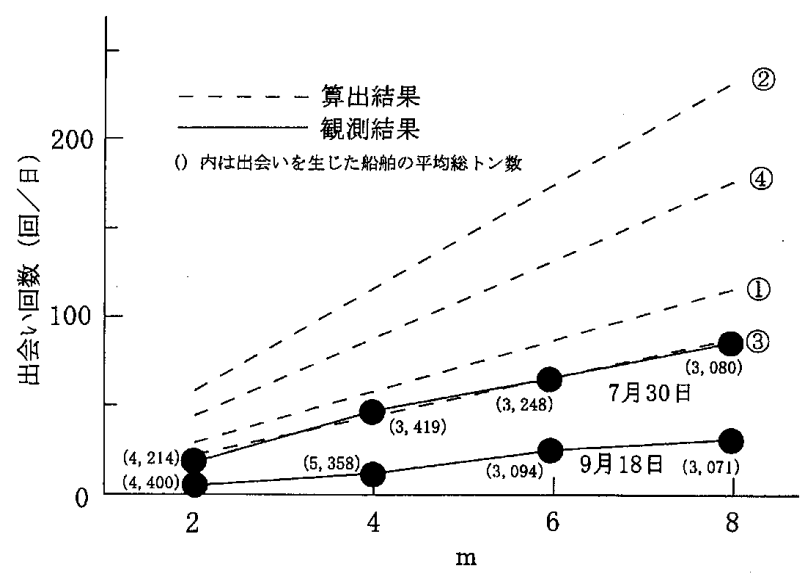

困 8 出会い回数を示すグラフ
て出会い回数を求めた。 $\mathrm{m}$ が 2 〜の範囲であれば 計算によって求めた出会い回数も実態観測から得た 出会い回数も比例関係となっていることがわかる。

ところで、交通実態観測から、対象水域内で船舶 の航行が観測されるのはおおむね昼間であり、夜間 は大型船舶の通航がほとんどないことがわかってい る。また、統計値から求めた同水域の1日あたりの交 通量 $(177,821 \times 2=355,642$ (トン) ) と7月30日に観 測された交通量 $(276,900$ (トン)) とが比較的近い ことから、上記のケース(4)と 7 月30日との出会い回 数は近くなると予想される。ところが、図 8 に示す ように両者にはおよそ2倍のひらきが生じている。 これは、

（a） 入港船舶は 07 時前後に集中して入り、出港 船舶は15時以降に多く、均一的な交通流ではない

（b） 水路の管制信号によって、大型船間での出 会いが生じないように配慮されている

(c) 避航操船による出会いの削減 などの影響が理由として考えられる。同図からわか るように、交通実態観測に基づく出会い回数とケー ス(3、すなわち、24時間かけて交通量が均一に出入 港すると想定した場合と極めて近い值を示してい る。交通管制などの規制がなく、12時間かけて均一 に交通流が流れるという計算に対して、上記の理由 が相乗的な効果を与えた結果が安全側になるためと 考之られる。すなわち、平均的に船舶が出入港する 場合よりも船船の出会いを減少させる方向に働いて いるためであると考えられる。結果的に、この対象 水域では 24 時間かけて均一な交通量の交通を想定し た場合と対応している。

\section{5. 出会い回数と衝突事故件数との関係}

神戸港の港域内においては、年平均約 25.6 件 （1996１998年の平均）の衝突事故が報告(6) されて いる。この対象水域には船船の入港に関する統計か ら算出すると、同港の約 $1 / 4$ の交通量がある。式(1) からわかるように、2つの交通流が交差する場合には 交通量の2乗に比例して出会い回数が増加する。ま た、水域内に交差の場所（ノード）が増えるに従っ て出会い回数も増加する。すなわち、同じ交通量で あっても交差の状態やノードの数など水域をとりま く環境によって出会い回数に差が生じるが、いまか クに、同水域が港全体からみて平均的な水域環境に あるものとし、さらに、衝突事故件数が交通量に比 例すると考之れば、同水域内で衝突事故の $1 / 4$ が発生 すると仮定できる。 $\mathrm{m}=2$ における年間出会い回数 $29 \times 365=10,585$ （回／年）につきおよそ $25.6 \times 1 /$ 
4(件) の衝突が生じていることになるから、衝突確

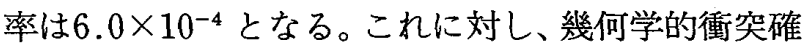
率 (衝突件数／幾何学的衝突回数) が、式 (5)および (6) での $\mathrm{m}=1$ に相当する場合で $0.9 \sim 1.6 \times 10^{-4}$ と される(4)。2 章の出会い回数の算出法による出会い 回数は、ケース(4)と策態観測結果とがおおよそ合致 することは先に示したとおりである。交通実態観測 に基づく航跡は避航操船が加わった結果であり、幾 何学的衝突回数はここでの出会い回数より多くなる ことを考慮すれば、衝突確率については非常に近い

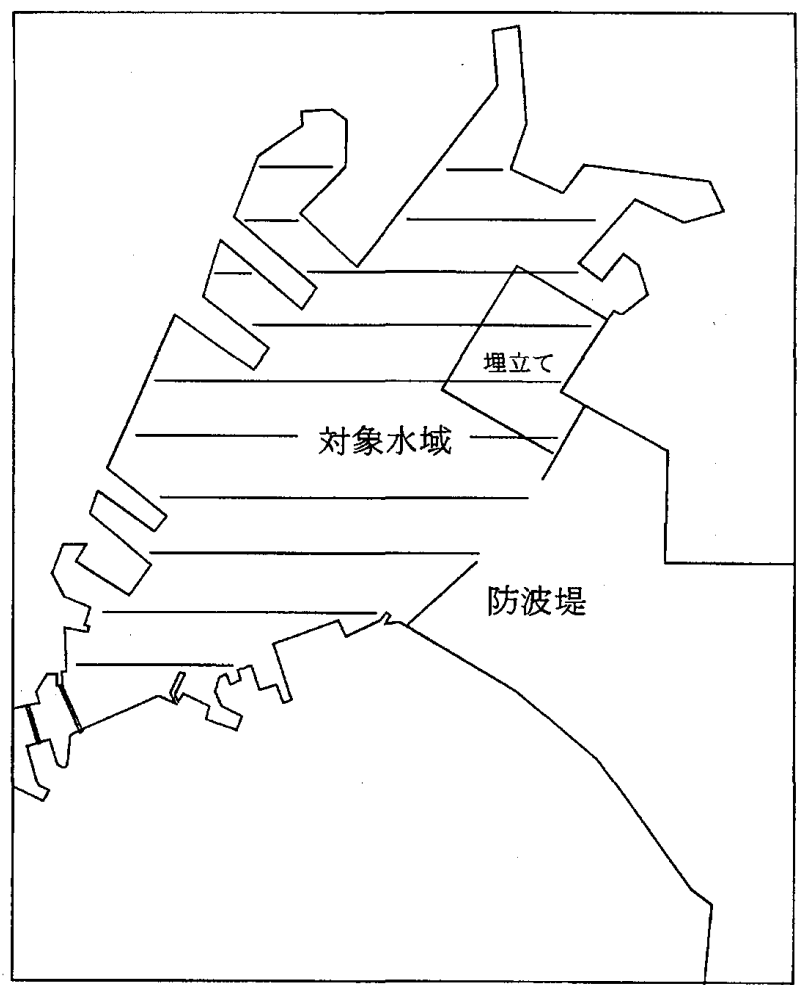

図 9 モデル港

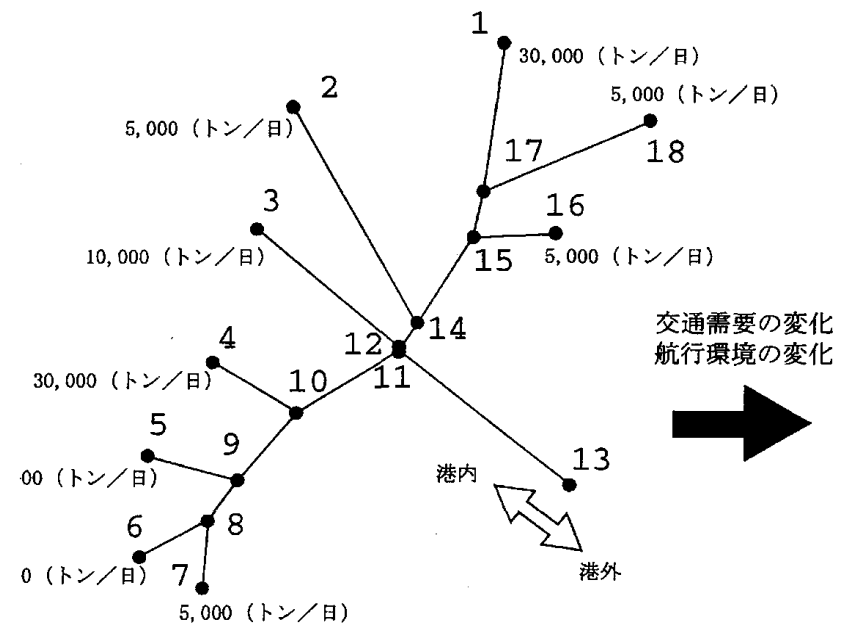

（a）現状のネットワーク
值となっている。

\section{6：交通環境変化の予測への応用例}

以上の結果を応用すれば、操船環境の将来の変化 に対する影響を予測することが可能となる。ただし、 ここでは将来的な交通需要の変化はあらかじめ与え られているものと想定する。

例えば、図 9 に示すような管制などの規制がない モデル港を想定し、同図内で示した領域が埋め立て られるとともに、交通量が将来的に 2 割増加するも のとする。埋立て前後のネットワークを想定すると 図10のとおりとなる。そして、

(1)現状

(2)将来

(3)ルート $1^{\prime} \Longleftrightarrow 13^{\prime}$ の交通を管制

(4)ルート $1^{\prime} \Longleftrightarrow 13^{\prime}$ および $4^{\prime} \Longleftrightarrow 13^{\prime}$ の交通を管制 (1)〜(4)のケースについて、2 章の手続きと同様にそ れぞれの出会い係数 $\mathrm{k}_{\mathrm{L}}$ および係数 $\mathrm{k}_{\mathrm{N}}$ を求め、日中の 12時間で交通量が均一に出入港すると仮定して出会 い回数を算出した結果を表 5 に示す。同表(2)の結果 から、この水域での出会い回数は、交通需要および 航行環境の変化によって約 6 割増加すると予想でき る。この場合、かりに神戸港の例のとおり、 $\mathrm{m}=2$ に おいて $6.0 \times 10^{-4}$ 程度の衝突確率があるとすると、

表 5 モデル港での出会い回数

\begin{tabular}{|c|c|c|c|c|}
\hline & $\mathrm{m}=2$ & $m=4$ & $m=6$ & $m=8$ \\
\hline (1)現状 & 26 & 52 & 78 & 104 \\
\hline (2)将来 & 42 & 85 & 127 & 170 \\
\hline (3) & 38 & 74 & 112 & 144 \\
\hline (4) & 28 & 56 & 83 & 111 \\
\hline
\end{tabular}

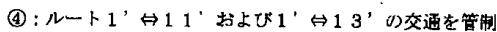

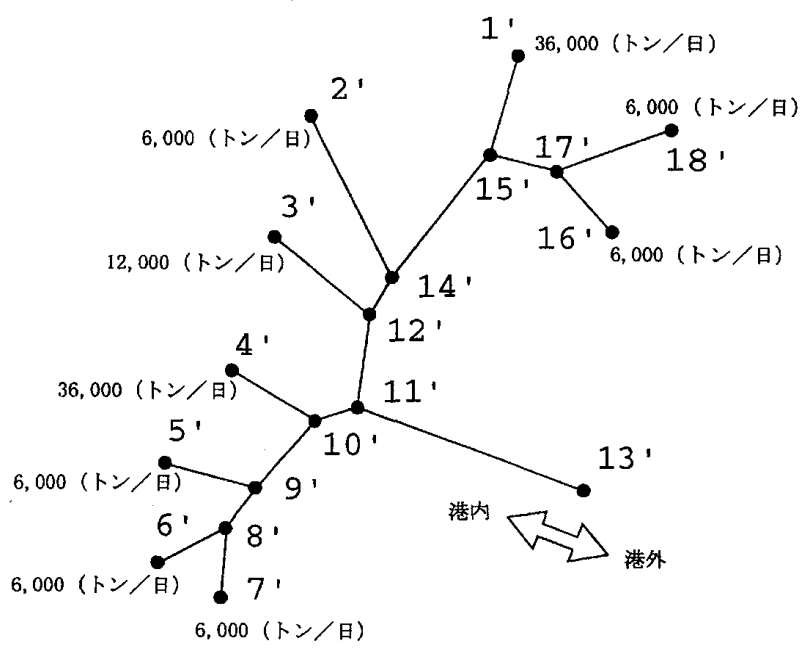

（b） 将来のネットワーク

困10＼cjkstart想定したネットワーク 
$(42-26) \times 365 \times 6.0 \times 10^{-4}=3.5$ (回 /年) の衝突事 故の増加が見込まれる。

そこで、大きな交通量をもつルート $1^{\prime} \Longleftrightarrow 13^{\prime} に つ$ いて出港，入港それぞれ 6 時間ずつを割り当て、同 ルートを経る交通量同士の出会いを完全に排除した 結果が(3)であり、この場合、将来的な出会い回数の 増加を4割程度までに抑えることができる。さらに、 ルート $4^{\prime} \Longleftrightarrow 13^{\prime}$ についても同様のタイムテーブル で交通を管制した結果が(4)であり、この場合、将来 的な出会い回数、すなわち、衝突事故を現状程度に まで抑えることができると考えられる。

このように、本研究の手法は、船舶の細かな、い わばミクロ的な挙動について言及することはできな いものの、港内などの広い水域における交通環境の 変化や交通管制などの安全化施策の効果をマク口的 に見ることができる。

\section{7.おわりに}

以上のように、2 章の出会い回数の算出の手法は、 先に文献(7)で報告したとおり、水域の形状から船舶 の経路を推定する手法を利用して船舶交通流のネッ トワークを想定することによク、実態観測に基づか なくともおよその出会い回数を算出ができることが わかった。本研究は出会い回数という「量」的評価 を行ったが、実際には各々の出会いは、その状況に よって「質」的な差異があるものと考えられる。こ のような「質」的な表現手法を確立し、水域の交通 環境のマク口的特性を表現することによって、水域 相互の質的な環境の比較手法へ発展できるものと考 える。

また、神戸港の限定された水域であるが、出会い 回数算出の手法による衝突確率と幾何学的衝突確率 がオーダーとして一致することは、ここでの手法が 比較的精度のよい結果を示すことを意味するものと 考えられる。この手法は単に現状の水域全体の出会 い回数を算出するにとどまらず、交通需要の変化や 埋立てなどによる交通環境への影響を予測する手段 となる。そして、出会い係数や平均水域幅を利用し て、水域全体からみて险路となる部分を抽出し、さ らに詳しく検討すべき水域を指摘することも可能と なる。

ここでの手法をそのままより広い水域に適用する ためには、解決すべき問題もあるものの、港内のよ うに限定された水域であれば、他の港についても同 様の結果が得られるものと考える。

\section{参 考 文 献}

(1) R. Ogniewicz, M. Ilg : Voronoi Skeletons : Theory and Applications, Proceedings CVPR'92, 1992.

（2）神戸市港湾整備局：神戸港大観，1999.

(3) 日本航海学会: 日本航海学会誌 NAVIGATION第80号（海上交通工学特集），1984.

（4）藤井弥平・巻島 勉·原 潔：海上交通工学, 海文堂, 1981 .

（5）日本写真測量学会：写真による三次元測定, 共 立出版, 1983.

（6）運輸省運輸政策局情報管理部：海難統計年報平 成8年～10年，1997 1999.

（7）田中・井上：水域環境のマク口的評価手法に関 する研究，日本航海学会論文集第100号，1999.

\section{質 疑 応 答}

中村紳也（日本郵船(株)）：ここでの手法は、「安全 性評価のカテゴリ一分類への適用」「詳細に検討す べきボトルネックの抽出」「他港との相対比較」な どへの応用が考えられますが、提案したマクロ的 評価を利用するにあたっての位置付けについて教 えてください。

田中隆博：本研究は、複雑化している現在のシュミ レーションとは逆に、統計值と水域形状という 2 つの情報からシンプルに交通環境を評価しようと いう試みですが、これによって、広い水域の中か ら特に詳細に検討すべき水域を抽出し、いわばミ クロ的なシュミレーションの効率的な実施の支援 への応用が可能と考えます。

宮坂真人（(株)エム・オー・マリンコンサルティン グ)：「リンク上における出会い」は直感的に理解 することができますが、「ノード上における出会 い」についての概念をもう少し詳しく御教授下さ い。

田中隆博：図 3 に示すように、幾何学的なネット ワーク上に交通流を想定した場合、リンク上にお いては図 5 (a)のように、同一の入出港流が行き 会うことによる出会いが生じます。また、ノード においては図 5 (b)のように、交通流の分岐によ る他の交通流との交差による出会いを考慮しなけ ればなりません。本研究では、同図のような共通 領域によって、交通流の交差による出会いを考慮 しました。 